\title{
PERSEPSI MAHASISWA TERHADAP PENGGUNAAN RUANG TERBUKA HIJAU DI UNIVERSITAS NEGERI JAKARTA DITINJAU DARI FUNGSI EKSTRINSIK
}

\author{
Irfan Husaini, ${ }^{1}{ }^{*}$, Henita Rahmayanti ${ }^{2}$, Amos Nelaka ${ }^{3}$ \\ ${ }^{1}$ Alumni Pendidikan Teknik Bangunan, FT UNJ, Jakarta, Indonesia. \\ 2 Pendidikan Teknik Bangunan, FT UNJ, Jakarta, Indonesia. \\ ${ }^{3}$ Pendidikan Teknik Bangunan, FT UNJ, Jakarta, Indonesia \\ ${ }^{*}$ Corresponding author:
}

\begin{abstract}
This research aim to determine student's perceptions toward green open space that has been there at the A Campus of State University of Jakarta reviewed from extrinsic functions. The research held at the A Campus of State University of Jakarta on June-July 2015.

The method used in this research was a descriptive research method with survey. Sampling population in this research are students which use green open space at the A campus of State University of Jakarta. Target population in this research are students of state university of jakarta which using green open space at crowded hour. Data collection conducted with questionnaire and documentation.

Results of this research are students' perceptions of the cultural dimension of the social function of the percentage reached $52.51 \%$ at one indicator assume this function has been reached, the dimensions of the aesthetic function is also considered to have achieved the highest percentage of $55.65 \%$ in one indicator, while the dimensions of the economic functions of the highest percentage of $46.86 \%$ is not considered an indicator of the implementation of this function well.
\end{abstract}

Keywords : Perception, Green Open Spaces, Extrinsic Functions, Surveys 


\section{PENDAHULUAN}

Universitas Negeri Jakarta (UNJ) atau yang dulunya bernama IKIP Jakarta merupakan lembaga pendidikan yang berdiri sejak tahun 1964. UNJ adalah satu-satunya Universitas Negeri yang terletak di tengah ibukota Jakarta. Kampus induk UNJ berada di jalan Rawamangun Muka yaitu kampus A sering juga disebut Kampus Barat. Kampus yang dulunya bekas Kampus Fakultas Keguruan IImu Pendidikan Universitas Indonesia ini memiliki luas lahan sekitar \pm 11,5 ha yaitu tepatnya sebesar $115.761 \mathrm{~m}^{2}$ terdiri dari bangunan gedung, jalan raya, selokan, taman serta parkir mobil dan motor. Lahan ini awalnya merupakan lahan yang dimiliki oleh Universitas Indonesia sebelum akhirnya pada 26 mei 1964 berubah kepemilikan menjadi milik Institut Keguruan dan IImu Pendidikan (IKIP) dan berubah nama lagi menjadi Universitas Negeri Jakarta (UNJ) pada tanggal 4 agustus 1999 hingga sekarang.

Dari Peraturan Menteri Pekerjaan Umum Nomor: 05/PRT/M/2008, RTH adalah area memanjang/jalur dan atau mengelompok, yang penggunaannya lebih bersifat terbuka, tempat tumbuh tanaman, baik yang tumbuh tanaman secara alamiah maupun yang sengaja ditanam. Dengan adanya tumbuhan-tumbuhan di dalam RTH ini, maka dapat memberikan kesempatan untuk merasakan hidup berinteraksi lebih dekat dengan alam.

Selain dalam lingkup lingkungan masyarakat luas, RTH juga memiliki peran yang penting di dalam lingkungan kampus. Hal tersebut terbukti oleh penelitian dari McFarland dkk., (2008) dari Texas State University, San Marcos, TX., yang berjudul Relationship Between Student Use of
Campus Green Spaces and Perceptions of Quality of Life yang telah dipublikasi pada jurnal ilmiah Hort Technology, 18: 196-319 membuktikan bahwa terdapat korelasi yang sangat nyata antara RTH di kampus dengan kualitas hidup, termasuk kualitas akademik para mahasiswa tersebut. Berturut-turut sebanyak $66,8 \%$ dan $24,1 \%$ mahasiswa termasuk pengguna "rutin" dan "medium" ruang terbuka hijau di kampus. Hanya sedikit $(9,1 \%) \quad$ mahasiswa yang "jarang" menggunakan RTH di kampus. Menariknya, pengguna menengah dan rutin $\mathrm{RTH}$ di kampus (yaitu total 90,1\%) menunjukkan persepsi yang sangat positif terhadap kualitas hidupnya. Mereka dikelompokkan pada kelompok yang sangat optimis terhadap kehidupannya. Secara umum dapat dikatakan bahwa mahasiswa yang menggunakan RTH di kampus mempunyai kemampuan yang tinggi untuk menghadapi tantangan pembelajaran dibandingkan dengan yang tidak atau jarang menggunakan fasilitas RTH.

Berdasarkan rumusan Direktorat Jenderal Penataan Ruang Departemen Pekerjaan Umum, 2006. ruang terbuka hijau adalah suatu lapang yang ditumbuhi berbagai tetumbuhan, pada berbagai strata, mulai dari penutup tanah, semak, perdu dan pohon (tanaman tinggi berkayu); Sebentang lahan terbuka tanpa bangunan yang mempunyai ukuran, bentuk dan batas geografis tertentu dengan status penguasaan tertentu, yang didalamnya terdapat tumbuhan hijau berkayu dan tahunan (perennial woody plants), dengan pepohonan sebagai tumbuhan penciri utama dan tumbuhan lainnya (perdu, semak, rerumputan, dan tumbuhan penutup tanah lainnya), sebagai tumbuhan pelengkap, serta benda-benda lain yang juga sebagai pelengkap dan penunjang fungsi RTH yang bersangkutan. 
Selain dari segi kuantitas, kualitas dari RTH UNJ juga harus diperhatikan. Terdapat fungsi-fungsi yang dapat mempengaruhi kualitas RTH sehingga dapat terlaksana dengan baik. Peraturan Menteri Pekerjaan Umum Nomor: 05/PRT/M/2008, menyatakan bahwa RTH memiliki 2 fungsi utama, yaitu fungsi intrinsik dan fungsi ekstrinsik. Fungsi intrinsik dari ruang terbuka hijau yaitu berupa fungsi ekologis sebagai infrastruktur hijau guna melindungi nilai dan fungsi ekosistem alami yang dapat memberikan dukungan kepada kehidupan manusia, seperti contoh yang paling dasar dan pasti adalah berasal dari beberapa tumbuhan di ruang terbuka hijau sebagai penghasil oksigen. Sedangkan fungsi ekstrinsik RTH berdasarkan Dirjen PU (2005) adalah pendukung dan penambah nilai kualitas lingkungan dan budaya kota tersebut, sehingga dapat berlokasi dan berbentuk sesuai dengan kebutuhan dan kepentingannya, seperti untuk keindahan dan rekreasi, dan pendukung arsitektur kota. Dapat dikatakan bahwa fungsi ekstrinsik merupakan kumpulan dari fungsi-fungsi penunjang RTH yang disesuaikan dengan kebutuhan dan kepentingan dari suatu lokasi sehingga dapat bermanfaat untuk manusia disekitarnya serta bermanfaat untuk RTH itu sendiri.

RTH sangatlah dibutuhkan diberbagai macam lingkungan, termasuk dalam lingkungan kampus. Karena RTH merupakan salah satu elemen perkotaan yang sangat penting untuk menunjang kehidupan dan aktivitas penduduk, dan pada dasarnya RTH merupakan unsur alamiah yang sangat berperan dalam mewujudkan kota yang berwawasan lingkungan (Branch, 1995). Maka berdasarkan fenomena diatas, dalam rangka mewujudkan keberadaan ruang terbuka hijau yang berfungsi secara maksimal dalam desakan kebutuhan akan ruang maka dilakukan kajian terhadap keberadaan ruang terbuka hijau di lingkungan kampus A UNJ. Selanjutnya dilakukan penelitian terhadap persepsi mahasiswa yang menggunakan RTH yang ada dikampus A UNJ mengenai fungsi ekstrinsik yang sudah dicapai.

\section{METODOLOGI PENELITIAN}

Metode yang digunakan dalam penelitian ini adalah penelitian survey dengan menggunakan instrumen kuesioner (angket) untuk menganalisa bagaimana pendapat mahasiswa terhadap fungsi ekstrinsik ruang terbuka hijau. Penelitian survey dilakukan pada populasi besar maupun kecil, tetapi data yang dipelajari adalah data yang diambil dari sampel tersebut. Penelitan ini tidak perlu mencari atau menerangkan saling hubungan, tes hipotesis, membuat ramalan mendapatkan makna dan implikasi. Neolaka (2014:21)

\section{HASIL PENELITIAN DAN PEMBAHASAN}

Dari hasil pengolahan data jawaban responden di dapatkan hasil persentase yang bermakna positif dan negatif pada masingmasing sub indikator. Positif menunjukan persentase tertinggi yang menunjukan tercapainya suatu sub indikator pada tiap dimensi. Sedangkan negatif menunjukan persentase tertinggi pada persepsi responden yang menganggap belum tercapainya sub indikator. 
Hasil Penelitian

Hasil Dimensi Fungsi Sosial Budaya

1. Indikator Ruang Publik

a. Media Berkumpul

- Positif $=$

- $\quad$ Negatif $=$

$52.51 \%$

$10.46 \%$

b. Rekreasi

- Positif $=$

$49.79 \%$

- $\quad$ Negatif $=$
$14.37 \%$
2. Indikator Area Pendidikan

a. Penelitian

- Positif $=$

$42.68 \%$

- $\quad$ Negatif $=$

$17.57 \%$

b. Tempat Belajar

- Positif =

$48.74 \%$

- $\quad$ Negatif $=$

$16.11 \%$

Hasil Dimensi Fungsi Estetika

1. Indikator perkerasan

a. Batu-batuan

- Positif $=$

$38.91 \%$

- Negatif =

$30.13 \%$

b. Site Furniture

- Positif =

- $\quad$ Negatif = $31.80 \%$

$34.45 \%$

c. Ornamen

- Positif $=$

- Negatif $=$
$30.96 \%$

$32.64 \%$
2. Indikator vegetasi

a. Warna tanaman

- Positif $=$ $41.14 \%$

- $\quad$ Negatif $=$

$23.57 \%$

b. Bentuk fisik tanaman

- Positif = $38.77 \%$

- $\quad$ Negatif = $21.20 \%$

c. Tekstur tanaman

- Positif $=$ $42.05 \%$

- $\quad$ Negatif $=$ $20.50 \%$

d. Skala proporsi tanaman

- Positif $=$ $41.00 \%$

- Negatif $=$ $25.94 \%$
3. Indikator Kenyamanan

a. Sirkulasi

- Positif =

$42.26 \%$

- Negatif $=$

b. Iklim

- Positif $=$

- Negatif $=$

c. Angin

- Positif $=$

- Negatif $=$
$20.92 \%$

$51.88 \%$

$15.06 \%$

$40.59 \%$

$23.85 \%$ 


\begin{tabular}{|c|c|c|}
\hline \multirow{2}{*}{\multicolumn{3}{|c|}{ d. Curah hujan }} \\
\hline & & \\
\hline - Positif $=$ & 39.75 & $\%$ \\
\hline - Negatif $=$ & 24.06 & $\%$ \\
\hline \multicolumn{3}{|l|}{ e. Kebisingan } \\
\hline - Positif $=$ & 44.98 & $\%$ \\
\hline - $\quad$ Negatif $=$ & 17.15 & $\%$ \\
\hline \multicolumn{3}{|l|}{ f. Aroma } \\
\hline - Positif $=$ & 37.66 & $\%$ \\
\hline - Negatif $=$ & 25.10 & $\%$ \\
\hline \multicolumn{3}{|c|}{ g. Bentuk elemen landscape } \\
\hline - Positif = & 55.65 & $\%$ \\
\hline - $\quad$ Negatif $=$ & 11.92 & $\%$ \\
\hline \multicolumn{3}{|l|}{ h. Kebersihan } \\
\hline - Positif = & 39.33 & $\%$ \\
\hline - $\quad$ Negatif $=$ & 20.92 & $\%$ \\
\hline \multicolumn{3}{|l|}{ i. Keindahan } \\
\hline - Positif = & 42.68 & $\%$ \\
\hline - $\quad$ Negatif $=$ & 18.41 & $\%$ \\
\hline
\end{tabular}

Hasil Dimensi Fungsi Ekonomi

\begin{tabular}{|lll|}
\hline $\begin{array}{l}\text { 1. Indikator Ekonomi langsung } \\
\text { a. Produksi tumbuhan }\end{array}$ & & \\
- Positif $=$ & 11.30 & $\%$ \\
- Negatif $=$ & 46.86 & $\%$ \\
b. Wirausaha & & \\
- Positif $=$ & 40.17 & $\%$ \\
- Negatif $=$ & 21.76 & $\%$ \\
\hline
\end{tabular}

Berdasarkan analisis data dari keselurahan faktor yang mempengaruhi kenyamanan pejalan kaki pada pemanfaatan trotoar pada pemanfaatan trotoar Segmen Jalan Pemuda, Kelurahan Rawamangun, Jakarta Timur, diperoleh pendapat positif responden dan pendapat negatif responden terhadap pernyataan angket (kuesioner) yaitu sebagai berikut:

\section{Pembahasan Hasil Penelitian}

1. Fungsi Sosial Budaya
2. Indikator Kesehatan

a. Konsumsi tumbuhan

- Positif $=$

$34.73 \%$

- $\quad$ Negatif $=$ $23.43 \%$

b. Olahraga

- Positif $=$

- $\quad$ Negatif $=$

$44.14 \%$

$20.71 \%$

Dalam suatu penelitian tentang manfaat psikologi area hijau Miller di dalam Rasyid (2014:34) diketahui bahwa tempat-tempat ini dapat memberikan manfaat dalam aspek bersosialisasi, memupuk keakraban dan kesetiakawanan, belajar bersama, memberikan kesempatan untuk mengeskpresikan pribadi dan nilai sosial, mempromosikan perkembangan rohani dan kejiwaan. Dari hasil kuesioner yang telah dijawab oleh responden, sebagian besarnya dengan persentase sebanyak $52,51 \%$ menganggap RTH pada UNJ telah menjadi media berkumpul yang dapat digunakan 
mahasiswa melaksanakan berbagai macam kegiatan seperti berkumpul dengan temanteman yang satu jurusan, atau bahkan berbeda jurusan hingga fakultas. Namun masih ada sebanyak 10,46 \% yang menganggap belum tercapainya RTH sebagai media berkumpul yang dibutuhkan,

Sebanyak 49,79\% menganggap RTH UNJ dapat menjadi tempat rekreasi bagi mahasiswa di tengah padatnya jadwal perkuliahan. Sebanyak $14,37 \%$ belum menganggap RTH UNJ dapat digunakan sebagai tempat rekreasi. Adanya laranganlarangan pada taman tanpa diimbangi dengan penyediaan fasilitas untuk berada didalam taman dapat mengurangi minat pengunjung di dalam taman. UNJ memiliki peminat taman yang cukup banyak, hal ini terlihat dari padatnya taman pada jam istirahat. Sayangnya selain taman yang padat, terlihat juga sangat kurangnya fasilitas yang kurang mendukung padatnya taman tersebut.

Responden sebanyak $42,68 \%$ untuk sub indikator penelitian dan $48,74 \%$ untuk sub indikator tempat belajar menganggap RTH UNJ telah tercapai menjadi sebuah area pendidikan. Namun, kurangnya pengoptimalan taman sebagai tempat penelitian dan tempat belajar sangat merugikan mengingat UNJ memiliki lahan yang cukup untuk RTH meskipun tak terlalu besar. Padahal menurut Hakam (2010:5) belajar dengan alam sebagai media akan menumbuhkan potensi-potensi dan bakat terpendam yang merupakan suatu kekhususan yang terdapat di dalam setiap individu.

\section{Fungsi Estetika}

Dari data hasil kuesioner yang telah dijawab oleh responden mengenai dimensi fungsi estetika untuk perkerasan batubatuan, dengan persentase terbesar $38,91 \%$ menyetujui RTH UNJ memiliki jalur setapak yang bagus dan menarik. Namun masih banyak yang memiliki persepsi bahwa RTH UNJ belum menyediakan jalur setapak yang diinginkan, masih adanya anggapan bentuk jalan setapak pada RTH UNJ masih monoton dan kurang memiliki daya tarik. Untuk site furniture masih banyak mahasiswa hingga $34,45 \%$ yang memiliki persepsi bahwa pada RTH taman-taman milik kampus A UNJ, masih banyak kekurangan furniture yang dapat memberikan rasa nyaman serta menampilkan estetika dari taman milik UNJ. Furniture yang telah adapun masih kurang tersusun rapih. Bentuk furniture kurang menarik dan terkesan biasa saja tanpa memperhatikan estetika yang dibutuhkan para pengguna. Sebanyak $32,64 \%$ menganggap ornamen/hiasan yang berada pada tiap RTH UNJ juga belum menunjukan identitas UNJ. Ornamen taman dapat disebut sebagai identitas suatu lokasi. Perletakan ornamen ini harus sesuai dengan fungsinya hingga dapat menunjukan identitas dari suatu lokasi. Hakim dalam Sembiring (2005:25).

Menurut Hakim (1991:71) Warna tumbuhan pada RTH ini harus diperhatikan, karena Warna dari suatu tumbuhan dapat menimbulkan efek visual tergantung pada refleksi cahaya yang jatuh pada tumbuhan tersebut. Warna tumbuhan dapat menarik perhatian manusia, binatang dan dapat mempengaruhi emosi yang melihatnya. Menurut responden, tumbuh-tumbuhan yang berada di RTH kampus A UNJ memiliki warna yang membuat nyaman dengan kolaborasi warna yang indah antara tumbuhan juga dengan lingkungan sekitarnya. Namun masih kurang dengan 
variasi warna tumbuhan, yang dapat menimbulkan kesan lebih indah. Berdasarkan hasil kuesioner, tumbuhtumbuhan pada RTH UNJ kampus A juga memiliki jenis tumbuhan yang bervariasi dengan bentuk indah dan menarik serasi dengan bangunan dan lingkungan $\mathrm{di}$ sekitarnya. Tekstur tumbuhan yang aman dan tidak melukai menambah menariknya RTH UNJ. Penataan ukuran tumbuhan dari pihak pengurus menambah nilai estetika dari RTH yang telah dimiliki UNJ kampus $A$. Namun kondisi yang baik tersebut belum diimbangi dengan perawatan secara merata di setiap RTH UNJ. Masih banyak RTH yang terlihat terbengkalai. Hal ini dapat menyebabkan RTH yang tidak terurus tersebut semakin rusak baik tumbuhtumbuhanannya, maupun fasilitasnya, sehingga mengurangi nilai estetika bagi yang melihatnya.

Data hasil kuesioner yang dijawab berdasarkan persepsi mahasiswanya mengenai kenyamanan, dimulai dari sirkulasi taman-taman yang dianggap terasa nyaman bagi para penggunanya. Jalan setapak serta tempat istirahat yang ada di taman-taman milik UNJ tidak terasa sesak walaupun banyak penggunanya.

Tumbuh-tumbuhan pada RTH UNJ mampu memberikan rasa kesan teduh dan sejuk juga dapat melindungi penggunanya dari angin yang mengganggu kenyamanan. Pada taman yang dimiliki UNJ terdapat juga tempat berlindung apabila terjadi hujan tiba-tiba. Rimbunnya daun, ranting dan batang pepohonan juga dapat mengurangi derasnya hujan secara langsung Suasana terasa tenang ketika berada di dalam lingkungan taman UNJ dikarenakan letak dari taman-taman UNJ itu sendiri memiliki jarak yang cukup dari jalanan umum, banyaknya pepohonan juga dapat mengurangi polusi suara. Namun hal tersebut masih kurang menyebar di beberapa taman. Terdapat RTH berupa taman aktif dan taman pasif di kampus A UNJ. Taman aktif berarti taman yang dapat dimasuki oleh penggunanya, sedangkan taman pasif tidak bisa. Kedua taman tersebut sudah dinilai indah oleh para mahasiswa. Bentuk berbagai macam elemen di dalamnya baik itu berupa tumbuhan maupun fasilitas-fasilitas penunjangnya tidak mengganggu pengguna maupun lingkungan di sekitarnya. Ketika berada di dalam taman milik UNJ tidak tercium aroma yang mengganggu, faktor kebersihan yang cukup diperhatikan di setiap taman UNJ serta perletakan TPS maupun perletakan RTH berupa taman yang tepat itu sendiri juga sangat mempengaruhi hal tersebut.

\section{Fungsi Ekonomi}

Menurut data hasil kuesioner yang sudah diperoleh dari penelitian, perolehan data menunjukan bahwa RTH UNJ dapat digunakan sebagai tempat untuk berwirausaha. Pihak kampus tidak melarang kegiatan perdagangan yang dilakukan mahasiswanya. Kegiatan perdagangan sering dilakukan ketika ada sebuah acara yang berlangsung di sekitar RTH maupun di dalam RTH itu sendiri. Pada hari biasapun tetap berlangsung kegiatan perdagangan yang dilakukan mahasiswanya. Penjualan jasa dari mahasiswa jurusan tertentu juga sering dilakukan di dalam RTH UNJ. Visual pada RTH UNJ serta keberadaan RTH itu sendiri dapat mengurangi perasaan stress mahasiswa. RTH UNJ juga dapat digunakan sebagai tempat untuk melakukan kegiatan olahraga tertentu. Karena lingkungan yang cukup memadai, RTH UNJ dapat menjadi tempat kumpul suatu komunitas olahraga. Pada beberapa titik, RTH UNJ terdapat tumbuh-tumbuhan dengan hasil produk yang 
dapat dikonsumsi. Hanya beberapa fakultas yang memiliki tumbuhan dengan hasil yang dapat dikonsumsi.

Menurut data hasil kuesioner yang sudah diperoleh dari penelitian mengenai penjualan produk, hingga $46,86 \%$ memiliki persepsi RTH UNJ tidak memiliki hasil tumbuhan baik itu berupa buah, getah, kayu, dan lain sebagainya yang dapat diperjualbelikan. Hal tersebut dapat dipahami karena RTH UNJ tidak memiliki tujuan khusus produksi ekonomi dalam pemanfaatan tumbuhannya. Diperlukan pemilihan tumbuhan yang tepat serta perawatan khusus yang dilakukan apabila RTH dibuat dengan tujuan untuk dijual segala hasilnya.

\section{KESIMPULAN}

Berdasarkan hasil penelitian, maka ditarik kesimpulan sebagai berikut :

1. Kuantitas RTH UNJ masih jauh dari standar sebesar $10 \%$ wilayah, yaitu baru $3 \%$ dari total luas wilayah keseluruhan.

2. Pada dimensi fungsi sosial budaya untuk indikator ruang publik dengan sub indikator media berkumpul dan rekreasi didapatkan persentase Sebanyak $52,51 \%$ dan $49,79 \%$ jawaban positif responden mahasiswa menganggap telah tercapainya tiap sub indikator. Pihak UNJ juga dianggap mahasiswa sebanyak $48,74 \%$ telah berupaya dalam penyediaan RTH sebagai area pendidikan yang bisa digunakan sebagai tempat untuk belajar para mahasiswa dan $42,68 \%$ untuk area penelitian.

3. Pada dimensi fungsi estetika dengan indikator perkerasan sub indikator batubatuan, persentasi positif sebanyak
38,91\% menganggap RTH UNJ telah memiliki jalur setapak yang bagus dan menarik menurut persepsi mahasiswanya. Namun persentasi negatif yang lebih besar dibandingkan positif didaptkan dari 2 sub indikator lainnya, yaitu $34,45 \%$ untuk site furniture dan 32,64 untuk ornamen. Pada indikator vegetasi, sub indikator warna tanaman, benuk fisik tanaman, tekstur tanaman, dan skala proporsi tanaman tergolong cukup dengan jumlah persentasi positif lebih tinggi dari negatif. Begitu juga pada indikator kenyamanan seluruh sub indikator yaitu sirkulasi, iklim, angin, curah hujan, kebisingan, aroma, bentuk area landscape, kebersihan, dan keindahan memiliki persentasi positif lebih tinggi, persentasi tertinggi dicapai sub indikator bentuk area ladscape yaitu hingga $55,65 \%$.

4. Mengenai dimensi fungsi ekonomi, 40,17\% responden menilai RTH telah berhasil digunakan sebagai tempat untuk berwirausaha dan $44,14 \%$ untuk olahraga, beberapa tumbuhan dalam RTH juga memiliki hasil yang dapat dikonsumsi oleh warga kampus. RTH UNJ tidak memiliki tujuan untuk memperjual belikan hasil tumbuhannya sehingga tidak dilakukan proses perawatan khusus baik dalam tingkat jurusan maupun tingkat universitas terhadap tumbuh-tumbuhannya sehingga didapatkan persentasi negatif yang tinggi yaitu $46,86 \%$ untuk sub indikator produksi tumbuhan. 


\section{DAFTAR PUSTAKA}

Aditya, Pandu. 2012. Penerapan Taman Atap (Rooftop Garden) Sebagai Alternatif Ruang Terbuka Hijau Pemukiman Kawasan Padang Bulan/Selayang. ilmu teknologi dan lingkungan, Universitas Airlangga Surabaya.

Agustinawati. 2010. Manajemen Strategi Ruang Terbuka Hijau (RTH) Dalam Upaya Peningkatan Kualitas Taman: Studi Deskriptif Pada Taman Kota Jakrta Utara. Pasca Sarjana, Universitas Negeri Jakarta.

Buku Pedoman Skripsi/Komprehensif/Karya Inovatif (S1). Jakarta: FT UNJ Press. 2009.

Dahana, Daka. 2012. Ruang Terbuka Hijau Pada Pelabuhan Penyeberangan. Departemen Arsitektur. Universitas Indonesia Depok.

Dewanti, Restu. 2013. Persepsi Guru Bimbingan Dan Konseling Mengenai Pelaksanaan Evaluasi Program Bimbingan Dan Konseling. Fakultas IImu Pendidikan,Universitas Negeri Jakarta.

Hakim, Rustam. 2013. Ruang Terbuka Hijau dan Ruang Terbuka Hijau. http://Rustam2000.wordpress.com. [Diakses tanggal 12 Maret 2015 pada pukul 04.00 WIB]

Hakim, Rustam. 1991. Unsur Perancangan Dalam Arsitektur Lansekap. Jakarta: Bumi Aksara.

Harahap, Reni Afriani. 2014. Studi Aktifitas Di Taman Sekitar Gedung Biro Pusat Administrasi Universitas Sumatera
Utara. Teknik Arsitektur, Universitas Sumatera Utara Medan.

Hasanah, Rini. 2013. Manusia dan Keindahan.

http://rinihas02.blogspot.com/2013/11/ bab-5-manusia-dan-keindahan.html. [Diakses tanggal 12 Maret 2015 pada pukul 04.00 WIB]

Jumeneng, Kuku Wahyu. 2009. Analisis Perubahan Penggunaan Lahan Dari Pertanian Ke Lahan Non Pertanian Di Kecamatan Wonosari Kabupaten Klaten Tahun 1996 dan 2005. Geografi, Universitas Muhammadiyah Surakarta.

Khan, Ihwan Ayub. 2010. Persepsi Siswa SMA Negeri Sekecamatan Duren Sawit Terhadap Materi Penjelajahan Gunung Dalam Mata Pelajaran Pendidikan Jasmani. Fakultas IImu Keolahragaan,Universitas Negeri Jakarta.

Komaruddin, 1994. Ensiklopedia Manajemen. Jakarta: Bumi Aksara.

Neolaka, Amos. 2008, Metode Penelitian dan Statistik. Jakarta: Rosda Karya.

Pandu Aditya. 2012. Penerapan Taman Atap (rooftop garden) sebagai alternative ruang terbuka hijau pemukiman kawasan padang bulan/selayang , medan. ilmu teknologi dan lingkungan departemen biologi fakultas sains dan teknologi. Universitas Airlangga.

Peraturan Menteri Pekerjaan Umum Nomor : 05/PRT/M/2008 Tentang Pedoman Penyediaan dan Pemanfaatan Ruang Terbuka Hijau di Kawasan Perkotaan. 
Peraturan Menteri Pekerjaan Umum Nomor : 06/PRT/M/2007 tentang Pedoman Umum Rencana Tata Bangunan Dan Lingkungan.

Peraturan Menteri Dalam Negeri Nomor 1 Tahun 2007 Tentang Penataan Ruang Terbuka Hijau Kawasan Perkotaan.

Rakhmat, Jalaluddin. 2004. Psikologi Umum. Bandung: Pustaka Setia.

Rasyid, Mujahidin Al. 2014. Analisis Ruang Terbuka Hijau Di Kampus A Universitas Negeri Jakarta. Teknik Sipil/Pendidikan Teknik Bangunan,Universitas Negeri Jakarta.

Sarwono, Sarlito W. 2002. Psikologi Lingkungan. Jakarta: Grasindo.

Sembiring, Erdawati. 2005. Analisis Tentang Fungsi Ruang Terbuka Hijau (Studi
Kasus : Taman Ahmad Yani Medan). Teknik Arsitektur/ Manajemen Pembangunan Kota. Universitas Sumatera Utara Medan.

Wiharnanto, Sri. 2006. Pengaruh Disain Arsitektur Elemen-Elemen Ruang Publik Terhadap Kunjungan Pengguna Kawasan (Studi Kasus Kawasan Pusat Perdagangan Oleh-oleh Jalan Pandanaran Semarang. Magister Teknik Arsitektur, Universitas Dipenogoro Semarang.

Wisuda, Amanda Putri. 2012. Analisis Pelaksanaan Kebijakan Perencanaan Pembangunan Taman Kota Sebagai Ruang Terbuka Hijau Di Kota Depok. IImu Administrasi Negara, Universitas Indonesia Depok. 